\title{
THE JURISDICTION IN EMINENT DOMAIN CASES IN PENNSYLVANIA UNDER ACT OF 1871.
}

It is proposed in this article to discuss the first section of the Act of June $19,187 \mathrm{I}^{1}$ as it is applied in eminent domain cases in Pennsylvania. The section in question purports to furnish a remedy against the unlawful acts of corporations, and, while the act is not so expressed, the question of its application has with a few exceptions, arisen where the defendant company is attempting to exercise the power of eminent domain, and the discussion will be confined accordingly:

The section in effect provides that where the private rights of individuals or corporations, or rights and franchises of corporations are invaded by the act of a corporation, the court shall, in any suit by the private party or corporation, inquire into whether the corporation doing the act does, in fact, possess the right or franchise to do the act complained of, and, if such rights or franchises have not been conferred upon such corporation, the court shall allow the recovery of damages if the action be at law, and, if in equity, shall restrain the doing of the act.

${ }^{2} P$. L. 1360, Scction 1, which is as follows: "In all proceedings in courts of law or equity of this commonwealth, in which it is alleged that the private rights of individuals or the rights or franchises of other corporations are injured or invaded by any corporation claiming to have a right or franchise to do the act from which such injury results, it shall be the duty of the court in which such proceedings are had, to examine, inquire and ascertain whether such corporation does in fact possess the right. or franchise to do the act from which such alleged injury to private rights, or to the rights and franchises of other corporations, results, and if such rights or franchises have not been conferred upon such corporation, such courts, if exercising equitable power, shall, by injunction, at suit of the private parties or other corporations, restrain such injurious acts; and if the proceedings be at law for damages, it shall be lawful therein to recover damages for such injury as in other cases." The Act of April 8, 1846, P. L. 272, entitled an act "relating to the chancery powers of courts in the City and County of Philadelphia," provides "that no courts within the City and County of Philadelphia, shall exercise the powers of a court of chancery, in granting or continuing injunetions against the erection or use of any public works of any kind, erected or in progress of erection, under the authority of an act of the legislature, until the questions of title and damages shall be submitted, and finally decided by a common law court." Wolbert v. Philadelphia, 48 Pa. 439 (I865); Wheeler v. Philadelphia, $77 \mathrm{~Pa} .338,344$ (1875); Wheeler v. Rice, $83 \mathrm{~Pa} .232$ (18;7); Flanagan v. Philadelphia, 8 Phila. 110 ( $\mathrm{Pa} .1870)$. 
It appears, when the act is closely examined, that it adds little to the existing law. Jurisdiction was exercised in equity before the act was passed, ${ }^{2}$ and an action of trespass would clearly lie at common law for an unlawful entry either by a corporation or an individual. ${ }^{8}$

It seems to have geen generally assumed, however, that the jurisdiction of the court to issue an injunction depends on the act ${ }^{4}$ and we shall, therefore, discuss it accordingly.

${ }^{2}$ Comm. v. Erie R. R. Co., 27 Pa. 339 (1856), bill by Comm. and injunction issued, restraining construction by a railroad company not in accordance with the terms of the charter; Stewart's App. $56 \mathrm{~Pa}$. 413 (1868); Jarden v. P., W. \& B. R. R., 3 Wharton 502 (1838); Unangst's App., 55 Pa. 128 (i867).

Jessup v. Loucks, $55 \mathrm{~Pa} .350$ (1867) was an action on the case for unlawful damming of a stream.

- No case since the act, other than an equity procecding, has been found where the landowner has raised the question of the power to condemn except: Philadelphia \& Merion Ry. Co.'s Petition, I87 Pa. I23 (I8g8) : Street railway filed a petition for appointment of viewers to assess damages for occupancy of a turnpike; latter company moved to quash the proceedings, on the ground that the petitioner liad no legal right to lay a street railway on the turnpike. Proceeding quashed; affirmed on appeal. The turnpike could raise the question, because it was not an avoidance of the charter, as non constat the street railway could lay the tracks somewhere else, but the street railway could not raise the question of forfeiture of the charter right of the turnpike to lay a street railway, on the ground of laches. A corporation without the power of eminent domain may invade the property of an individual or the franchise of a corporation, but if such an act is a trespass, there is a remedy in equity apart from the Act of $187 \mathrm{I}$, e. g., Alexander v. Coal Co., $254 \mathrm{~Pa}$. I (IgI6) ; Nugent v. Mining Co., $263 \mathrm{~Pa} .230$ (1919); Packard v. Theil College, $209 \mathrm{~Pa} .340$ (1904) [Act of I87I referred to not in point.]

- It is clear that the railroad is not covered by the alleged charter, "which if inquired into by the commonwealth in a quo warraito might end in a judgment of ouster. This power of inquiry by the first section of the Act of June 19, 1871, P. L 1360, may be excrcised by this court, where, as in this case, the private right of an individual is injured and invaded by this corporation, claiming to have a right or franchise to do the act from which such injury results." Reed, J., in McCandless's Appeal, 7o Pa. 210, 216 (1872). Gordon, J., said the Act of June 10, 1871 P. L. I36I enables a private citizen by bill in equity, to call upon a corporation to show by its charter that it has the power to do a certain act, or, on the other hand, the complainant may show from the charter that powers once possessed by the corporation have been forfeited by lapse of time or otherwise. The act contemplates nothing more than that it shall be made to appear from the charter that the said corporation has the power to do the act in question. It does not authorize a private citizen to assume the position of the Commonwealth. Western Penna. R. R. Co.'s Appeai, 104 Pa. 399 (1884).

"An inquiry as to whether certain powers are or are not conferred by a charter is not open to the objection that the validity of the charer is assailed in a collateral proceeding. Such inquiries are expressly authorized by the Act of June Ig (1871)." Sterrett, J., in Sterling's Appeal, III Pa. 35, 40 (I886).

"In some of the earlier cases effort was made to stretch the act to 
The remedy by injunction is very necessary, because when a landowner excepts to the appointment of viewers in the court

confer on private parties the authority previously exercised by the commonwealth to inquire into the abandonment or forfeiture of franchises, but -it was held that the act did not confer on the individual the general authority of the commonwealth, but that under it the inquiry must be restricted ta the existence of franchises as shown by the charter: W'estern Penna. $R$. $R$. Co.'s Appeal, 104 $\mathrm{Pa} 339$. Hence the terms of the grant in the charter were usually spoken of as the test of the validity of the corporation's action, and, so far as the grant is concerned, that is still, as it always has been, the conclusive test. But it was never decided or intended to be that the failure of the grant could not be shown cither from the charter itself or aliunde. Thus, in the case last cited, it was held that the complainant might show from the charter that the franchise had lapsed or expired, and the cases on passenger railways, cited supra, rest on proof outside of the charter that other legal requirements for the validity of the challenged action were wanting. The language of the charter therefore is not the sole test of the validity of the acts complained of. The purpose of the act of 1871 was to enable individuals to protect their private property and rights against unlawful and unauthorized interference by corporate action directly and without the necessity of invoking the aid of the commonwealth. The injury to the complainant is the same whether the illegality or want of authority arises from the charter or otherwise. What he challenges is the existence of present lawful authority to do the thing that injures him, and to that end he may avail himself of any defect in the authority set up, however arising." Mitchell C. J., in Edwards v. R. R. Co., $215 \mathrm{~Pa} .597,603$ (1906). Inquiry under the Act of $387 \mathrm{r}$ is "always limited to a consideration of the question 'Does the corporation possess the power to do what it is attempting to do?' and not whether it is exercising its powers in an improper manner." Elkin, J., in Colliery Co. v. R. R. Co., $226 \mathrm{~Pa}$. 131, 135 (1910). The Act (1871) applies to direct invasion of rights, not consequential injuries resulting from contractual relations and the inquiry is limited in suits by private partics to the question of charter powers." Elkin, J., in Blankenburg v. R. Transit Co., $228 \mathrm{~Pa} 338$ (1910).

"This act $(18, \mathrm{I})$ permits an individual to contest the right of a corporation to do certain acts. It has been uniformly held that under this act, the inquiry is limited to the question whether or not the defendant has the right or power to do the particular act complained of. If it appears such power exists, the authority of the court to interfere is at an end." Frazer, J., in Williams v. D., L. \& W. R. R., $255 \mathrm{~Pa}$. 133, I44 (1916). In Mountz v. R. R. Co., $265 \mathrm{~Pa} .67$ (1919), where the Supreme Court affirmed the refusal to issue a preliminary injunction restraining the construction of a branch road, the court below [King, P. J.] said that under the Act of 1871 , the courts have the right of inquiry at the instance of a private party, but that inquiry is limited to the nature and extent of the franchise prima facie conferred by the charter itself, and that, if the corporation defendant is abusing its franchise or is acting in bad faith with a purpose of evading its duties as a public service corporation, the Commonwealth is the proper party to inquire. Sce discussion by Moschisker, C. J., in Gring v. Water Co., $270 \mathrm{~Pa} .232$ (192r), and statement on pages $238-239$ where he said that it "will be found that the cases where relief was granted all fall within one of the following classes: (1) those in which the corporation had no charter right to do the thing complained of (2) those in which, though the power was apparently given by the corporation's charter, it was attempted to be exercised in a manner, for a purpose or to an extent not authorized by law; (3) those wherein a power, that ordinarily would exist under the charter, was attempted to be exercised in violation of an agreement previously made by the corporation, which, under 
below and the exceptions are dismissed, the order is interlocutory, and an appeal by the landowner will be dismissed. ${ }^{-}$If the exceptions are sustained, the order is final as to the corporation, which may appeal, and on the appeal the landowner may raise the questions he might under the Act. of $1871 .^{7}$ So also the order approving the bond filed in the statutory proceedings decides nothing, as to the power.to condemn is interlocutory and not appealable by statute. ${ }^{\overline{\bar{g}}}$ The court may withhold approval of the bond pending determination of the question in the equity proceedings. ${ }^{\circ}$

The general principles of equity practice are applicabie, and the court will not take jurisdiction when the title is in dispute, ${ }^{10}$ nor will an injunction issue when the inconvenience to the defendant is greater than the inconvenience to the plaintiff." Since, however, the landowner is entitled to protection from an unlawful taking, irrespective of the amount of the damages, it. is

the attending circumstances, was to be viewed "as though named in the charter"; (4) those in which, though ample power was given by the charter, it was conditioned upon the precedent doing of certain things that had not been done; (5) those wherein the power granted by the charter was to be exercised only on consent of some other public body or bodies, and such consent had not been granted, or had been given on a condition which had not been fulfilled or had been broken; (6) those in which, though the power was conferred is defendant's charter, some other corporation, also having power so to do, had precedently exercised its like right, and, under the circumstances, it would have been illegal or inequitable to disturb the latter." . See Pioneer Coal Co. v. R. R. Co., $272 \mathrm{~Pa} .43,48$ (1922).

- Water Co. v. Gring, 257 Pa. 340 (Igr7) ; Wàter Co. v. Brumbaugh, 246 Pa. 225 (1914).

'Philadelphia \& Mierion Ry. Co.'s Petition, 187 Pa. I23 (I8g8); Crescent Pipe Line Co.'s Petition, $56 \mathrm{~Pa}$. Super. 201 (1914); Phila. Parkway, $258 \mathrm{~Pa}$. 252 (I9I7); but see Kensington Plan, 2 Rawle 445 (1830); Petition of Barngor, etc, R. R Co., 8 P2. Dist. R. 65 (1898).

'Silocum's Appeals, 12 W. N. C. 84 ( $\mathrm{Pa}$. 1882) ; Water Co: v. Brumbaugh, $246 \mathrm{P2} 225$ (1914); Market Co. v. R. R. Co., 142 P2. 580 (189r); Blandburg Water Co.'s Condemnation, $233 \mathrm{~Pa} 230$ (I9II) ; Getz v. P. \& R. R. $\mathrm{R}$., I Walker $427(\mathrm{~Pa}, 1879)$. The owner filed a bill for an. injunction, and the condemnor filed a plea setting up the statutory proceedings and filing of the bond and approval thereof, whereupon the court dissolved the preliminary injunction and relegated the owner to his remedy on the bond. The Supreme Court on certiorari refused to review the action of the court in approving the bond, which approval settled nothing as to the right of the company to condemn. R. R. Co. v. Gamble, $204 \mathrm{~Pa}$. 198 (I902), order fixing amount of bond not appealable.

' Kincaid v. R. R. Co., 25 Pa. Co. Ct. 545 (rgor).

"Marshall v. Pa. Co., $44 \mathrm{~Pa}$. Super. 68 (1910).

"Becker v. Street Railway, $188 \mathrm{Pz} 484$ (1898). 
not necessary to allege or prove irreparable damage. ${ }^{12}$ The landowner will be barred by laches just as in other equity proceedings.. ${ }^{13}$ The owner may not, however, urge that a particular damage will be inflicted when he has an adequate remedy at law for the particular damage. ${ }^{14}$

In granting a preliminary injunction the court will be governed by the considerations usually applicable in such cases. ${ }^{15}$

2 Groff's Appeal, $128 \mathrm{~Pa}$. 621 (1889). Construction of turnpike rosd would have benefiled plaintiff. Hophins $\vee$ Manufacturing Co., $180 \mathrm{~Pa}$. I99 ( 18$\left.)_{j}\right)$; Citizens Electric $\mathrm{Co}$. $\checkmark$. Boom Co., $227 \mathrm{~Pa}$. 448 (1910); bill in equity filed against the Boom Co. to compel the opening of the gates of a dam. Plaintiff had a right under a deed from $A$ to the use of a strip of land for a mill race to convey water to mills to be erected by the grantee, and fur no other use whatsoever. Mills were destroyed in 1889 , and never rebuilt, so plaintiff had no right to have the water come down to the mill -ace. The defendant company had acquired the premises under eminert domain so the remedy of the plaintiff was on the bond for damages, and in no event would equity issue an injunction.

"Landowner barred by laclses in the following cases: Hankey v. Phila: delyhia Co., $5 \mathrm{~Pa}$. Super. 148 (1897) : Maust v. St. Ry., 219 Pa. 568 (1908); Condron v. I'a. R. R., 233 Pa.. 197' (1911); Groff v. Turnpike Co., $144 \mathrm{~Pa}_{2}$ 150 (189I); Biddle v. llater Works, $190 \mathrm{~Pa} .94$ ( $\mathrm{Y} 8 \mathrm{mg}$ ). Viewers made report and landowner had appealed and bill in equity filed thereafter; Keeling $\checkmark$ R. R. Co., $205 \mathrm{~Pa} .31$ (1903); Injunction filed by abutting owner against carrying out of contract between $R$. $R$. Co. and city. Contract executed April 13, 1901, bill filed June $2 \%, 1901-$ in the meantime the $\dot{R}$. $R$. Co. had begun work and spent money. Stewart Wire Co. v. Lehigh Navigation Co., $203 \mathrm{~Pa}$. 474 ( $\left(\mathrm{y}_{02}\right.$ ) : Injunction refused riparian owner against diversion of water after delay of many months. Damage trifling and easily compensated by action at law. Youse v. McCarthy, 51 Pa. Super. 306 (I912), standing by for time less than statutes of limitations; bill dismissed without prejudice, action at law brought $23 \mathrm{~Pa}$. Dist. R. 760 (19I4). Chew v. Phila., $25:$ Pa. 589 (1917); McClane v. McClane, $213 \mathrm{~Pa} .286$ (1906); s. c: $207 \mathrm{Pz}$. 465 (1904): The court rested the case on the ground of estoppel of the plaintiff to contest the defendant's right of way. Bill sustained on terms that $R$. $R$. Co. comply with a certain agreement to maintain crossings. Wilson Township v. Faston Transit Co., $258 \mathrm{~Pa}$. 266 (1917): Township standing by and acquiescing in certificate of public convenience by Public Service Commission cannot subsequently have an injunction restraining construction of a street railway on ground of lack of proper consent by Township. Act. of I871 not mentioned.

"Williams v. D., L. \& W. R. R., 255 Pa. 133 (1916): Failure to provide farm crossings. Murdoch v. Pittsburg, $256 \mathrm{~Pa}$. 268 (I9I7): Removal of switch in strect by changing grade.

${ }^{23}$ Preliminary injunction granted. Boro. v. R. R. Co., 24r Pa 357 (1913); Pfoutz v. Telephone Co., 27. C. C. R. 602 (I902); Peifly v. Water Co., 214 Pa. 340 (I006). Preliminary injunction refused. Eastman v. Water Co., $222 \mathrm{~Pa}$. 355 (1908); Murdoch v. Pittsburg, $256 \mathrm{~Pa}$. 268 (I9I7); Mountz v. R. R Co., $365 \mathrm{~Pa} .67$ (I919); Lejee v. R. R. Co., 10 Phila. 362 (1875); Nugent v. Mining Co., $263 \mathrm{~Pa}$. 230 (Igrg); $R$. $R$. Co. v. Coal Co., et al, $24 \mathrm{~Pa}$. Co. Ct rn $(1900)$; Boro v. Electric Transmission $\mathrm{Co}_{0,} 32 \mathrm{~Pa}$. Co. Ct 91 (1900), $\mathrm{Pa}$ R. R. v. Street Railway Co., $176 \mathrm{~Pa} .559$ (1896). Preliminary injunction is- 
The plaintiff has no standing to apply for an injunction unless he can show clear title to a special property which will be damaged by the act of the corporation defendant. Therefore, a borough cannot have an injunction to restrain occupation of its streets by a street railway which has power to lay its tracks without municipal consent. ${ }^{10}$. A private citizen has no standing to compel specific perfomance of a contract entered into between the municipality, of which he is a citizen, and a street failway company relating to rates of fare. ${ }^{17}$ :Individuals not owners of abutting property cannot complain of the unlawful construction of a street railway in the street. ${ }^{18}$ A railroad company cannot enjoin the construction of a street railway on the ground that operation of the street railway diminished its receipts. ${ }^{19}$. A stockholder of a street railway cannot restrict the company from occupying the streets of a city. ${ }^{20}$ A railway company whose right of way crossed a turnpike and which owned in fee the abutting land on each side of the turnpike at the point of crossing, is not entitled to an injunction restraining a street railway from constructing its tracks on the turnpike, the company having the consent of all the other owners. ${ }^{21}$ The court, furthermore, will not take jurisdiction where the title is in dispute. ${ }^{22}$

Nor will an injunction issue when it clearly appears that the defendant company is not intending to take the land without filing a bond. ${ }^{23}$

sued and dissolved when bond filed and approved by the court, Bland $v$. Water Co., $222 \mathrm{Pz} .285$ (1908).

"Borough v. R. R. Co., $205 \mathrm{~Pa} .402$ (I903).

${ }^{18}$ Blankenburg v. Rapid Transit Co., $228 \mathrm{~Pa} .338$ (1910).

"Andel v. Si Ry., 219 Pa. 635 (rgo8): The plaintiffs were individuals who had filed articles of association in the office of the Secretary of the Commonwealth, but to whom no letters patent had been issued, and it was held on that ground also, that they had no standing.

s Penna. R. R. v. Street Ry. Co., 176 Pa. 559 (1896).

"Seitz, ct al., v. Traction Co., 5 Pa. Co. Ct. 469 (I888).

${ }^{2} \mathrm{~Pa}$. R. R. v. Street Ry. Co., 176 Pa. 559 (1896), R R. Co. v. Traction Co.; $205 \mathrm{~Pa} .579$ (I905).

"Marshall v. R. R. Co., 44 Pa. Super. 68 (19ro) ; Street Ry. v. Street Ry., $219 \mathrm{~Pa} .558$ (1908), semble.

${ }^{2}$ Hey v. Water Co., $207 \mathrm{~Pa} .38$ (1903). 
The court will not inquire into whether a charter has been forfeited by failure (a) to complete the works within the time fixed, ${ }^{24}$ (b) by abandonment, ${ }^{23}$ (c) by failure of bona fide organization within a certain time, ${ }^{26}$ (d) or by failure in good faith to commence the construction of the works. ${ }^{27}$ Nor will the court inquire whether the charter has expired by non-user of grant, ${ }^{28}$ nor grant an injunction on the ground that a water company is supplying a part of the water outside the territorial limits. ${ }^{2 g}$ In like manner a landowner may not raise the question of the eligibility of the directors of the defendant corporation to act as directors in passing the necessary resolutions, ${ }^{30}$ nor any question of the proper exercise of discretion by the directors of the company as to the amount of land needed, ${ }^{31}$ nor set up.that the defendant railroad company was composed of the unlawful merger of two parallel and competing roads. ${ }^{32}$

An abutting owner may have an injunction against an unlawful occupation of a township road amounting to an additional servitude, ${ }^{33}$ against occupation of a street without lawful

*Olyphant, etc., Co. v. Olypharıt Boro., Ig6 Pa. 553 (1900) : Bill by boro to restrain construction on boro str eets. Hoffman's Appeal 1o W. N. C. 401 (Pa. 1882); Gas \& Water Co. v. Downington, 193 Pa. 255 (1899): Bill by water company to restrain interference by boro, which could not set up failure of plaintiff to furnish sufficient water. Injunction issued.

${ }^{3}$ Western Pennsylvania R. R. Co.'s Appeal, 104 Pa. 399 (1884): Injunction refused plaintiff to prevent another company from crossing its tracks at grade. Decree entered providing manner of crossing. Affirmed on appeal.

* Lejee v. St. Ry. Co., Io Phila. 362 (1875).

"Turnpike Company v. Electric Ry., $\stackrel{-}{-}$ a.

${ }^{2}$ Hinchman v. Tumpike Co., I60 Pa. 150 (I894), dictum.

- Croyle v. Water Co., 259 Pa. 484 (Ig18); Panther Valley Water Co. v. R. R. Co., $43 \mathrm{~Pa}$. Co. Ct. 315 (1915): $\mathrm{R}$. R. unlawrully appropriating water trom a stream cannot set up, in defense to $a$ bill in equity by water company, a lower riparian owner which had earlier condemned, the circumstance thiat plaintiff had exceeded its charter rights in furnishing water for industrial purposes.

Williams v. D., L. \&. W. R. R., 255 Pa. 133 (1916).

"Chew v. Phila., 257. Pa. 589 (I9I7); Tibby Bros. Gas Co. v.. Pa. R R, 219 Pa. 430 (1908); Price v. Pa. R. R., $209 \mathrm{~Pa} 81$ (1904); see Mountz v.. R. R. Co., $265 \mathrm{~Pa} .67$ (1919).

Tibby Bros. Glass Co. v. Pa, R, R, $219 \mathrm{~Pa} .430$ (1908).

- Young v. Transmission Co., $32 \mathrm{~Pa}$. Co. Ct. 81 (I906); Pfoutz v. Telephone Co., 27 C. C. R 602 (1902), erection of poles; Sterling's Appeal, III Pa. 35' (1886), laying of pipes; Pa. R. R. v. Pass. R. Co., 167 Pa 62 (1895); injunction granted railroad company as owner in fee against construction of a street railway company, which had not obtained local consent of all authorities along the route. 
authority, although not an additional servitude ${ }^{34}$ and against use of the street contrary to law. ${ }^{35}$

The power of eminent domain must be exercised in strict compliance with the statutory requirements and, therefore the landowner may have an injunction restraining the taking unless and until the requirements have been complied with. Thus, if the corporation proceeds without filing a bond, an injunction will issue restraining further proceedings until a bond has been filed. ${ }^{30}$ So also the court will inquire into the sufficiency and form of the resolution locating the works, ${ }^{3 i}$ and into the validity of a city ordinance providing for widening and changing the grade of a street. $^{38}$

Condemnation by a water company will be restrained where it appears that the water to be appropriated will be supplied to the public outside the territorial limits of the company ; ${ }^{39}$ but

"Hopkins v. Mfg. Co., I80 Pz. I99 (1897); Wirth v. St. Ry. Co., 2 W. N. C. 650 (Pa 1876); Penna. R R. Co.'s Appeal,.115 Pa. 514 (1886); Barker v. Hartman Steel Co., I29 Pa. 551 (i8s); Potts v. Elevated $R$ R., $16 I P_{2}$. 396 (I894); Hannum v. Street Ry. Co., 200 P2. 44 (1901); Morey v. R. R. Co., $199 \mathrm{P2} 152$ (I901).

Edwards v. R. R. Co., 215 Pa. 597 (1906).; Hannum v. Ry. Ca., 221 $\mathrm{Pa} .454$ (1908), injunction refused.

${ }_{4}^{4}$ Bly v. Water Co., 197. Pa. 80 (1900); Bland v. Water Co, $222 \mathrm{~Pa}_{2} 285$ (1908); but where the company has used the water for sixteen years before plaintiff purchased the land, the fact that bond filed has not been approved is immaterial. Blauch v. Water Co., $247 \mathrm{~Pa} .7 \mathrm{I}$ (1915); Davis v. Pipe Lines, $34 \mathrm{~Pa}$. Super. 438 (I907), affirmed $223 \mathrm{~Pa} .56$ (I909); injunction issued unless corporation, within period fixed, proceeds according to law. An action of trespass had previously been brought and recovery had for nominal damage. Sterling's Appeal, III Pa. 35 (1886) ; Tumpike Co. v. Railway Co., I77 Pa. 585 (18g6); see Rudolph v. R. R. Co., 166 Pa. 430 (1895): bill dismissed; and Rudolph i.' R. R. Co., I86 Pa. 54I (i898): stautory proceedings.

"Williams v. D., I. \& W. R. R., $255 \mathrm{~Pa}$ I33 (1916). Sec Pioneer Coal Co. v. R.R. Co., $272 \mathrm{~Pa} .43$ (J922), where failure of condemnor to prove that resolution was passed by the directors was held immaterial.

Murdoch v. Pittsburg, $256 \mathrm{~Pa}$. 268 . (1917): there is no right to an injunction where the bond has been filed in proper proceedings, the title having been divested and the owner relegated to the remedy on the bond, Citizens' Electric Co. v. Boom Co., $227 \mathrm{~Pa} .448$ (Igro). Where, in 2 proceeding against a water company under the Act of $187 \mathrm{I}$, the chancellor finds that a necessity existed for a greater supply of water in the "territory presently served" by defendant and another company which it had leased, but the record fails to show that the certificate called for by the Act of June $7,190 \%, \mathrm{P}$. I. 455 , to validate the lease, had been filed, a decree for defendant will be reversed, and the case remitted for hearing as to whether such certificate had been filed, and for such other findings and conclusions as may be demanded by the facts developed, and the effect which must be given to the Act of 1907 , as the court may view it; Gring v. Water Co., $270 \mathrm{~Pa} 232$ (Igar).

sly v. Water Co., I97 Pa. 80 (1900). 
where a part only of the water is to be supplied outside the limits, the injunction will be refused, the partial unlawful user being a matter only for the Commonwealth to inquire into. ${ }^{10}$

It has been said by way of dictum that the landowner can raise the question of whether the land condemned is reasonably necessary to the conduct of the business of the company. ${ }^{11}$

A municipal corporation may have an injunction against occupation of its street without its consent, if consent is necessary, and to enforce compliance by a street railway with condition annexed to grant of right to use streets. ${ }^{42}$

A public use may be plaintiff, and have an injunction restraining another corporation exercising the power of eminent domain, from taking any of its property without lawful authority. In these cases the court will inquire into whether in fact the condemning corporation has shown sufficient necessity for the taking, in addition to the lawful authority. ${ }^{* 3}$ So also one railroad company may have an injunction restraining another railroad company from crossing its tracks. ${ }^{44}$ An injunction will

- Bland v. Water Co., 222 Pa. 285 (Ig08); see opinion of Brown, J., at p. 290; Croyle v. Water Co., $259 \mathrm{~Pa} 484$ (1918); Mier v. Water Co., 250 P2. 536 (1915): case slumbered for twelve years without prosecution; Blauch v. Wiater Co., $247 \mathrm{~Pa} .71$ (ror5).

- Elkin, J., in Raystown Water Co. v. Brumbaugh, $246 \mathrm{~Pa} .225,228$ (1914); sce Burkhard v. Water Co., 254 Pa. 41 (I912); Boalsburg Water Co. $v$. Water $\mathrm{Co}_{0} 240 \mathrm{~Pa}$. Ig8 (1913): court inquired into wherher the company was attempting to condemn more water than its necessities required.

a Phila. v. P. \& R. R. R, 25 W. N. C. 320 (Pa. 1889) ; McKeesport v. Ry. Co., 12 Pa. Dist. R. 541 (1903) : no reference to Act of 1871.

- Appeal of Sharon Ry. Co., I22 Pa. 533 (1888); R. R. Ca.s Appeal, 222 Pa. 511 (I\&86); Boalsburg Water Co. v. Water Co., $240 \mathrm{~Pa}$. I98 (igr3); Schuylkill Valley R. R. v. Philadelphia \& Reading R. R, $157 \mathrm{~Pa} .42$ (1893); $160 \mathrm{~Pa} .232$ (1894); 167 Pa. 576 (1895).

${ }^{4} \mathrm{R} . \mathrm{R}$. Co. y. R. R. Co., $193 \mathrm{~Pa} 127$ (1899). Same case on preliminary injunction: $186 \mathrm{~Pa}$. 212 (I8g8). Where one $R \cdot R$ Co. has the burden of maintaining a crossing of its line by a narrow gauge $R$. $R$, it may raise the question of the power of the narrow gauge $R . R$. Co. to widen its gauge, and accordingly a bill by the narrow gauge $R . R$ Co. for an injunction to restrain the aforesaid mentioned $R$. $R$. Co. from interfering with the widening, will be dismissed where it appears that narrow guage $R . R$. Co. has no power to widen; $R$. $R$ Co. v. $R$. R. Co., $241 \mathrm{~Pa}$. 608 (I9I3): injunction granted a standard gauge railroad company against a grade crossing of its tracks by a narrow gauge railroad without authority to make the crossing. Western Penna. R. R. Co.'s Appeal, 99. Pa. I55 (I88I); Western Penna. R. R. Co.'s Appeal, I04 Pa. 399 (1883); Passenger Ry. v. Passenger Ry., 151 Pa. 138 (1892), s. c. 31 W. N. C. $28 \mathrm{I}$ (Pa. I892); affirming $9 \mathrm{~Pa}$. Co. Ct. 638 (I89I). 
also issue to restrain laying tracks in sireet already occupied by tracks of complainant. ${ }^{45}$

There is a conflict in authority in answer to the question whether the landowner can have an injunction on the ground of improper use of the franchise, where the power of eminent domain is granted. The real principle involved scems to be this: If the improper use goes to the heart of the enterprise, so that there will be no taking. if there is only a proper use, the landowner should have an injunction; but if the taking would be carried out, even if confined to a proper use, the question should be left to the Commonwealth, as an injunction would be useless, since the corporation could immediately turn around and make a re-entry confining itself to a proper use. ${ }^{\text {io }}$

- Passenger Ry. v. Passenger Ry., 15 Pa. Co. Ct. 498 (1894) : preliminary injunction refused as plaintif's case was not clear at carly stage of the proceedings. St. Ry. v. St. Ry. Co., $219 \mathrm{~Pa} .558$ (Ig03); Light and Power Co.'s Appeal, 27 Pa. Co. Ct. 1 (1902) ; St. Ry. Co. v. Ry. Co., 206 Pa. 40 (1903): injunction issued to prevent interference with exclusive privilege in highway during period fixed in Act of Assembly.. St. Ry. v. St. Ry., 137 P2. 533 (1890); St. Ry. v. St. Ry., 18 Pa. Super. 524 (1901); inj. refused.

P. R R. v. Lilly Boro., 207 Pa. I80 (1903): application by R, R. Co. for an injunction to restrain borough from interfering with construction of telegraph lines along defendant's right of way in public highway of the. borough. - Injunction refused as the railroad had the right to construct the line and the court could not inquire into the purpose of the company in constructing the telegraph nor into the use intended to be made by it. Windsor Glass Co. v. Carnegie Co., $204 \mathrm{~Pa} .459$ (1903): hill alleged that the corporation was a cloak for the operation, under a railroad charter, of a private railroad operated exclusively for the benefit of the defendant's manufacturing plant. Court refused the injunction and said that the inquiry was into the conduct of the defendant under the charier, a matter exclusively for the Commonwealth, and that the real complaint was that the defendant did not furnish passenger car stations or freight cars for public use. That Edgewood R. R Co.'s Appeal, $79 \mathrm{~Pa}$. 257 (1875) was a case, not of omission to. do ucts authorized by the cliarter, but of the doing of acts not authorized by the charter. Colliery Co. v. R. R. Co., $226 \mathrm{~Pa}$. I3I (I9ro): injunction refused against a corporation chartered under the Act of 1868 . Plaintiff alleged that proceeding was ari unlawful attempt to procure a railroad for private use. Court below fourd that public necessity demanded construction and operation of the road; that the statement of the witnesses fully explained away the seeming doubtfal actions of the defendant company. See however: Laird v. Pittsburg, $205 \mathrm{~Pa}$. I (I903) : bill in equity by owner to restrain city from condemning land for a public park on the ground that the city intended to use the land in order to extend a free library and art building already standing on other laxd (part of the public park). Bill dismissed. Mitchell, J., said, at page I4 that the bill might be dismissed on the technical grounds that the power of the city to acquire land for park purposes is undisputed and the ordinance and proceedings regular, but that nevertheless the case will be dealt with on the merits, the real ground of controversy being 
An injunction will issue when the evidence shows that the works about to be constructed are authorized by another act of assembly, even though the act under which the defendant is proceeding clearly confers the power of eminent domain. ${ }^{47}$.

As the pawer of eminent domain in Pennsylvania can only be exercised by corporations having public duties, the court will issue an injunction whenever the power is attempted to be exercised by private individuals or private business companies. ${ }^{48}$

that the use proposed to be made of the land is not within the legitimate scope of park purposes. Howley v. Central Valley $R . R, 213$ Pa. 36 (1905): owner had interfered with the construction of a railroad chartered under the Act of 1868 , and had been perpetually enjoined from such interference. After the construction had proceeded, he applied for an injunction on the ground that it was proposed to operate the road with electricity. The court brushed aside the objection that the question could not be raised and after lengthy discussion refused the injunction.

"Thus an injunction will issue against the construction of a railroad although defendant incorporated under the Act of 1868 , and charter powers are clear, when the evidence shows that the road is to be constructed and used as an electric railway; Morey v. $R . R$ Co., $199 \mathrm{PL}_{2}$ 152 (Ig01), abutting owner obtained injunction against construction in a borough street. Kincaid v. $R . R . \mathrm{Co}_{0}, 25 \mathrm{~Pa}$. Co. Ct. 545 (IgOI), owner obtained injuriction against taking of part of his land. Edgwood $R$. $R$. Co.'s Appeal, 7o $\mathrm{Pa} .257$ (1875), injunction issued against the construction of a railroad chartered under the Act of 1868 and supplement, as it was in fact a lateral railroad and should have bcen constructed under the statutes applicable. Collins v. Northeastern Elev. R R. Co., 2 Pa. Dist. R 417 (1893); Gaw v. R. R. Co., I96 P2. $44^{2}$ (I900), s. c. II Montg. Co. Rep. 73 (Pa.); the owner failed to prove that the construction under the Act of 1860 was for the purpose of evading the former decree of the court and supplying the necessary lines in street railway system. Oliver v. Thompson's Run Bridge Co., 197. Pa. 344 . ( 1900$)$, s. c. II Montg. Co. Rep. $73(\mathrm{~Pa})$; Contended that the bridge was being built to obtain passage across a ravine for a street railway, which otherwise could not cross. Supreme Court recognizing the validity of the contention, said the facts showed a public necessity for the bridge, apart from the street railway.

- Stewart's Appeal, $56 \mathrm{~Pa}$. 4I3 (1867), contruction of railroad by individual without authority. McCandless's Appeal, jo $\mathrm{Pa} 210$ (1872): injinction issued directing the removal of a private railroad built by private parties without authority of law. The road had been enjoined (Stewart's Appeal, $56 \mathrm{~Pa}$ 413 [I867]), and then sold to a railioad company duly incorporated. Peifly y. Water Company, 214 Pa 340 (1906) : the court grented 2 preliminary injunction saying that under its charter the defendant company was presumably a corporation for private purposes, and could not constitutionally be invested with the power of eminent domain. $\mathrm{Phila}_{2} \mathrm{Cl}_{2 \mathrm{y}} \mathrm{Co}$. v. York. Clay Co., 24I Pa. 305 (Igr3): construction of private tramway under Act of June 5, 1911, P. I 167 , on a private road laid out under Acts of April 4. I901, P. L. 65, and May 17, 1901, P. L 259. Public had no right to use the tramway and therefore there was no public use.-The defendant was a private business company having no public duties and therefore could not be invested with the power of emineint domain, and, as the act did not declare the tramway, which was to be constructed, a public use, the question whether 
An injunction was issued in one case ${ }^{48}$ where it was decided that the act authorizing the construction was unconstitutional because the use was private, and in another case ${ }^{50}$ the court refused to consider the unconstitutionality of the incorporating act, which was defective in that the subject.matter was not clearly expressed in the title.

The cases are difficult to reconcile and it is believed that the earlier case expresses the true view. If the owner cannot, by injunction, protect property from invasion under an unconstitutional act, he is practically without a remedy.

-The court is required by the act to ascertain whether the defendant corporation does in fact possess the right to do the act, and if the power has not been conferred to issue an injunction against the doing of the act. There is a slight inconsistency here, because the corporation may have clear legislative power and yet the surrounding circumstances may lead to the conclusion that the power conferred may not be exercised. There are two views of the construction of the act, which are contending for supremacy in the opinions of the Supreme Court. ${ }^{51}$ One is that, when the power is conferred,

it was such, is to be determined by the court under all the facts of the case.

Waddell's App., $84 \mathrm{~Pa} .90$ ( 1877 ), construction by individual of privato right of way under the unconstitutional act of June 13,1874 P. L. 286 .

When a bill in equity is filed against a water company to restrain it from exercising the right of eminent domain on the ground that the company is merely a corporation for private use, a preliminary injunction is properly refused where it is established to the satisfaction of the court that the defendant is a public service corporation; Eastman v. Water Co., 222 Pa. 355 (Ig08), facts obscurely reported.

- Waddell's Appeal, $84 \mathrm{~Pa} .90$ (1877).

* Burkhard v. Water Co., $234 \mathrm{~Pa}$ 4I (1912).

"In the following cases of corporations chartered under the Act of 1868, the facts alleged by the owner were held insufficient to warrant the issuing of an injunction: Getz's Appeal, 10 W. N. C. 453 (Pa. I88I); siding to private property. Rochester Coal Co. v. R. R Co., $24 \mathrm{~Pa}_{2} \mathrm{Co}$. Ct. I04 (1900), branch to private mining operation; Mounts v. $R \cdot R$ Co., $265 \mathrm{~Pa}$. 67 (1919); Pioneer Coal Co. v. R. R. Co., 272 Pa. 43 (Ig22), acc. Slocum's Appeal, I2 W. N. C. 84 ( $\mathrm{Pa}$ I882), straightening track, acquiring siding to facilitate general freight business. Price v. $P . R$, $200 \mathrm{~Pa} 81$ (Iga4), construction of branch line used exclusively for freight; Rudolph v. R. R. Co., $166 \mathrm{~Pa} .430$ (I\&95), ace. Deemer v. R. R. Co., 212 Pa. 491 (rgo5), construction of railroad through undeveloped country. Market $C o$. v. $R . R$.Co., $142 \mathrm{~Pa} 580$ ( $189 \mathrm{r}$ ), construction of elevated railroad in a city; injunction refused, semble. Injunction refused in these cases, where legislative grant of powers held ample; Bigler v. Penna. Canal Co., I77 $\mathrm{Pa} .28$ 
the jurisdiction of the court is at an end, and further inquiry is to be made by the Commonwealth. The other is that the landowner may set up facts outside the charter, and the court may be justified by those facts in restraining the exercise of the power conferred by the legislature. The burden is on the landowner of showing clearly that the power conferred should not be exercised. ${ }^{52}$

\section{Philadelphia, $\mathrm{Pa}$.}

Roland R. Foulke.

(1806); Chew v. Phila., 25; Pa. 589 (1917); Hespenheide's Appeal, 4 Penny. ir (1)a. i\&4), power of eminent domain of lessee of railruad; Brumbaugh v. Power Co., 254 Pa. 215 (1916), bill fled after bond filed in the statutory proccedings; Jacob v. Water Co., $220 \mathrm{~Pa}$. 388 (1908); Boyd v. Negley, $53 \mathrm{P2}$ 38; (1K66), lateral railroad located, viewers appointed damages assessed, construction begun and owner filed bill to restrain building. Dismissed. Owner averred: a. That the road was not being built on the route located. Court found that it was, and that if the proceedings did not describe the road located, the crror was amendable, and not to be considered at this late date. $b$, That the grade of the road had been changed. The court found no evidence of such change. Burkhard v. Water $\mathrm{Co}_{1} 234 \mathrm{~Pa}$ 4I (I9I2), the court refuscd an injunction after discussing questions whether there had been an effort to agrce and whether the power had been exhausted by a previous condemnation, but said the owner could not set up the unconstitutionality of act of incorporation. Hey v. Water Co., $207 \mathrm{~Pa} .3^{8}$ (I903), where condemning company was proposing to supply in the territories of twelve other companies, the court examined the question of whether the defendant company could lawfully acquire by purchase the franchise of the other companies and whether it had acquired the powers of the other companies. Both questions were answered in the affirmative, and injunction refused. In Young v. Transmission Co., $32 \mathrm{~Pa}$. Co. Ct. $8 \mathrm{I}$ ( 1906$)$, the owner filed a bill contending inter alia, that the deiendant company was incorporated under an act of assembly which did not give it the power to make the entry in question. This company set up a charter uncer another act. Held that the court was bound by the provision of the charter as to the act of incorporation, but injunction issued on ground that defendant was without authority to occupy without local consent.

secmer v. R .R. Co., 2I2 Pa. 49 I (1905); Pioneer Coal Co. v. R. R. Co., 272 Pa. 43 (Ig22). 